\title{
UJI ANTIOKSIDAN EKSTRAK ETANOL DAUN DAN KULIT BATANG MANGGIS Garcinia mangostana L.
}

\section{ANTIOXIDANT ACTIVITY OF ETHANOLIC EXTRACT OF Garcinia mangostana L. LEAVES AND SKIN BARKS}

\author{
Diniatik, Suparman, Dewi Anggraeni, Ibnu Amar \\ Fakultas Farmasi Universitas Muhammadiyah Purwokerto \\ Jl. Raya Dukuhwakuh PO BOX 202, Purwokerto 53182, Central Java, Indonesia \\ Email:diniatik@yahoo.com.au
}

Submitted: 28-12-2015

Reviewed: 22-02-2016

Accepted: 13-05-2016

\begin{abstract}
ABSTRAK
Antioksidan merupakan senyawa yang dapat menghambat reaksi radikal bebas dalam tubuh. Penelitian ini bertujuan untuk mengetahui aktivitas penangkapan radikal bebas dari ekstrak etanol daun dan kulit batang G. mangostana L., serta untuk mengetahui berapakah aktivitas penangkapan radikal bebas ekstrak etanol daun dan kulit batang G. mangostana L., pembanding vitamin E (d- $\alpha-$ tokoferol). Pengukuran aktivitas penangkapan radikal bebas dilakukan dengan menggunakan metode DPPH terhadap ekstrak etanol daun dan kulit batang G. mangostana L. dengan seri konsentrasi 800 $\mathrm{ug} / \mathrm{mL}, 400 \mathrm{ug} / \mathrm{mL}, 200 \mathrm{ug} / \mathrm{mL}, 100 \mathrm{ug} / \mathrm{mL}$. Hasilnya menunjukkan ekstrak etanol daun dan kulit batang mempunyai aktivitas antioksidan $674,947 \mathrm{ug} / \mathrm{mL}$ dan $565,759 \mathrm{ug} / \mathrm{mL}$ terhadap radikal bebas DPPH. Hasil analisis varian satu arah pada taraf kepercayaan 95\%, ekstrak etanol daun dan kulit batang $G$. mangostana L. mempunyai aktivitas antioksidan yang sama, namun berbeda terhadap pembanding Vitamin $\mathrm{E}\left(\mathrm{IC}_{50} 57,114 \mathrm{ug} / \mathrm{mL}\right)$ yaitu lebih kecil 11 dan $10 \mathrm{kali}$.
\end{abstract}

Kata kunci: antioksidan, ekstrak etanol daun dan kulit batang G. mangostana L., DPPH (1,1 diphenil-2-pikrilhidrazil), vitamin E (d- $\alpha$-tokoferol)

\section{ABSTRACT}

Antioxidant was a compound which possessed an activity as scavenger of free radicals. This study was aimed to examine the antioxidant activity of ethanolic extract from leaves and skin barks of Garcinia mangostana. Antioxidant activity were evaluated by using DPPH method for ethanolic extract in serial concentration of $800,400,200$ and $100 \mathrm{ug} / \mathrm{mL}$. The result found that ethanolic extract of leaves and skin barks of Garcinia mangostana showed antioxidant activity with $\mathrm{IC}_{50}$ value of $674.947 \mathrm{ug} / \mathrm{mL}$ and $565.759 \mathrm{ug} / \mathrm{ml}$, they were eleven and ten times weaker than $\mathrm{d}$ - $\alpha$-tocopherol $\left(\mathrm{IC}_{50}\right.$ $57,114 \mathrm{ug} / \mathrm{mL}$ ) which were used as a control. In conclusion, EE from leaves and skin barks of Garcinia mangostana exhibited an activity as scavenger of free radicals from DPPH.

Keywords: ethanolic extract of Garcinia mangostana leaves and skin barks, antioxidant activity, $\mathrm{DPPH}$, vitamin $\mathrm{E}$ (d- $\alpha$-tocoferol)

\section{PENDAHULUAN}

Makanan yang diharapkan dikonsumsi lebih dari satu hari memerlukan bahan tambahan pangan yang disebut sebagai pengawet, untuk menghindari kerusakan makanan seperti tumbuhnya mikroorganisme berupa bakteri, kamir atau kapang pada pangan yang dapat merusak protein, kemudian berakibat timbulnya bau busuk, dapat membentuk lendir, gas, busa, asam, serta racun. Sampai saat ini sebagian besar pengawet masih lebih menggunakan bahan kimia, diantaranya Asam Benzoat, Asam Propionat, Asam Sorbat, Belerang Oksida, Etil p-Hidroksida Benzoat, Kalium 
Benzoat, Kalium Bisulfit, Kalium Meta Bisulfit, Kalium Nitrat, Kalium Nitrit, Kalium Propionat, Kalium Sorbat, Kalium Sulfit, Kalsium benzoate, Kalsium Propionat, Kalsium Sorbat, Natrium Benzoat, Metil-p-hidroksi Benzoat, Natrium Bisulfit, Natrium Metabisulfit, Natrium Nitrat, Natrium Nitrit, Natrium Propionat, Natrium Sulfit, Nisin, Propil-p-hidroksi Benzoat (Permenkes Nomor : 722/Menkes/Per/IX/88). Makanan juga bisa rusak karena adanya proses oksidasi sehingga dibutuhkan antioksidan. Dengan demikian dalam pengawet sekaligus antioksidan sangat dibutuhkan untuk menjaga stabilitas kandungan gizi dalam makanan.

Antioksidan dapat dibedakan dalam dua macam yaitu dalam sistem pangan dan dalam sistem biologis. Keduanya mempunyai prinsip yang sama yaitu mencegah proses oksidasi. Dalam sistem biologis, antioksidan dimaksudkan melindungi kerusakan sel tubuh dari kerusakan akibat proses oksidasi. Salah satu caranya dengan mengkonsumsi produk alami yang kaya akan antioksidan, seperti sayuran dan buah-buahan (Winarsi, 2007). Dalam sistem pangan, antioksidan dimaksud melindungi kerusakan pangan akibat dari proses oksidasi, sahingga ketika masuk ke dalam tubuh, maka makanan dapat berfungsi dengan baik sebagai sumber nutrisi bagi tubuh. Beberapa tanaman berpotensi sebagai antioksidan dalam sistem pangan, salah satunya ada pada genus Garcinia yang banyak ditemukan senyawa xanton, benzofenon, depsidon dan triterpen yang bersifat antibakteri, antoksidan, dan antikanker. Secara tradisional beberapa spesies dari genus Garcinia telah digunakan untuk pengobatan. Keragaman manfaat tumbuhan Garcinia sebagai obat tradisional tersebut terkait dengan kandungan kimianya. Beberapa spesies dari genus ini telah diteliti secara berkesinambungan baik kandungan kimia maupun aktivitas biologinya. (Muharni et al, 2009).

Berdasarkan latar belakang tersebut maka dapat dirumuskan permasalahan sebagai berikut : Apakah ekstrak etanol daun dan kulit batang G. mangostana memiliki aktivitas sebagai antioksidan serta berapa perbandingan aktivitas antioksidan ekstrak etanol daun dan kulit batang G. mangostana terhadap standar vitamin e? Tujuan penelitian ini adalah mengetahui aktivitas antioksidan dari ekstrak etanol daun dan kulit batang G. mangostana dan mengetahui perbandingan daya antioksidan dari ekstrak etanol daun dan kulit batang G. mangostana terhadap vitamin E.

\section{METODE PENELITIAN \\ Determinasi tumbuhan}

Determinasi dilakukan di Laboratorium Biologi Farmasi Fakultas Farmasi Universitas Muhammadiyah Purwokerto.

\section{Pengumpulan bahan}

Daun dan kulit batang G. mangostana diambil kabupaten Banyumas, Jawa Tengah. Pengeringan dilakukan dengan meletakkan bahan yang telah dicuci bersih pada tampah, kemudian ditutupi dengan kain hitam supaya tidak terkena sinar matahari langsung. Setelah itu dijemur dibawah sinar matahari sampai kering. Simplisia yang telah kering (dengan memperhatikan persyaratan kandungan air maksimal dalam simplisia) diserbuk dan ditempatkan dalam botol coklat yang kering.

\section{Pembuatan ekstrak etanol daun dan kulit batang G. mangostana $\mathrm{L}$.}

Simplisia daun dan kulit batang ditimbang $\pm 2 \mathrm{~kg}$ dibuat serbuk melalui proses penggilingan dan pengayakan. Serbuk kering ditimbang \pm 500 gram kemudian dimaserasi. Maserasi dilakukan dengan cara merendam serbuk simplisia dalam cairan penyari. Pada penelitian ini untuk meningkatkan efektifitas ekstraksi dilakukan pengadukan dan remaserasi, dimaserasi selama 2 x 24 jam dengan perbandingan antara simplisia dengan etanol $70 \%$ adalah 1:10 untuk hari pertama, dan 1:4 untuk hari kedua. Caranya yaitu serbuk simplisia sebanyak 500 gram dimaserasi dengan etanol $70 \%$ sebanyak 5 Liter, kemudian dienap-tuangkan dan diperas. Ampas yang diperoleh dimaserasi lagi dengan etanol $70 \%$ sebanyak 2 Liter. Sari etanol diuapkan sampai diperoleh konsistensi kental yang masih bisa dituang kemudian ditimbang. Pembuatan ekstrak etanol daun dan kulit batang G. mangostana dilakukan di Laboratorium Biologi Farmasi Universitas Muhammadiyah Purwokerto. 


\section{Pengukuran aktivitas penangkapan radikal bebas}

Pengukuran aktivitas antioksidan dilakukan terhadap ekstrak etanol daun dan kulit batang $G$. mangostana L. dengan seri konsentrasi $800 \mathrm{ug} / \mathrm{mL}, 400 \mathrm{ug} / \mathrm{mL}, 200 \mathrm{ug} / \mathrm{mL}$, dan $100 \mathrm{ug} / \mathrm{mL}$. Pengukuran aktivitas antioksidan ekstrak etanol daun dan kulit batang $G$. mangostana L. dilakukan dengan menggunakan metode DPPH. Atom hidrogen atau kemampuan mendonorkan elektron dari ekstrak etanol daun dan kulit batang G. mangostana L. diukur dari hilangnya warna ungu dari larutan DPPH dalam metanol menjadi warna yang jernih. Pengukuran dilakukan menggunakan spektrofotometri. Reagen yang digunakan adalah senyawa radikal stabil DPPH (diphenylpicrylhidrazyl) (Gulluce, et al.,2006).

Lima puluh mikroliter dari seri konsentrasi ekstrak etanol daun dan kulit batang $G$. mangostana L. dilarutkan dalam metanol. Kemudian ditambahkan 0,004\% larutan DPPH dalam metanol hingga $5 \mathrm{~mL}$. Setelah diinkubasi selama 30 menit pada suhu ruang, absorbansi dibaca pada $517 \mathrm{~nm}$ menggunakan blanko. Penghambatan radikal bebas dari DPPH dalam persen (I\%) dihitung menggunakan rumus :

$\mathrm{I} \%=($ Absorbansi tanpa sampel-Absorbansi sampel/Absorbansi tanpa sampel $) \times 100 \%$,

Konsentrasi ekstrak yang menunjukkan $50 \%$ hambatan $\left(\mathrm{IC}_{50}\right)$ dihitung dari kurva hubungan persentase hambatan dengan konsentrasi sampel. Senyawa antioksidan sintetis yang digunakan sebagai kontrol positif adalah $\alpha$-d-tokoferol (vitamin E) (Gulluce, et al.,2006).

\section{Analisis}

a. Data yang diperoleh dari pengukuran aktivitas penangkapan radikal bebas berupa persen penghambatan (I\%).

b. Data yang diperoleh berupa persen penghambatan (I\%) dianalisis lebih lanjut untuk mengetahui harga $\mathrm{IC}_{50}$-nya, yaitu menggunakan persamaan regresi linier pada kurva hubungan antara persen hambatan dengan konsentrasi ekstrak (Gulluce, et al.,2006).

\section{HASIL DAN PEMBAHASAN}

Pada penelitian ini menggunakan tanaman manggis (Gambar 1) yang diambil di desa Rawaheng, Kecamatan Wangon, Kabupaten Banyumas dan desa Somagede, Kecamatan Somagede, Kabupaten Banyumas. Kulit batang segar tanaman manggis diambil pada bulan Januari 2011 dan daun segar diambil pada bulan Februari 2011 pada pagi hari pukul 08:00-11:00. Kulit batang dan daun yang diambil ialah yang sudah tua, karena diharapkan diperoleh kandungan kimia yang sudah optimal (Anonim, 1985). Pengambilan dilakukan pada tempat dan waktu tertentu untuk menghindari bermacam-macam kandungan kimia dikarenakan perbedaan kondisi lingkungan, keadan tanah, dan iklim.

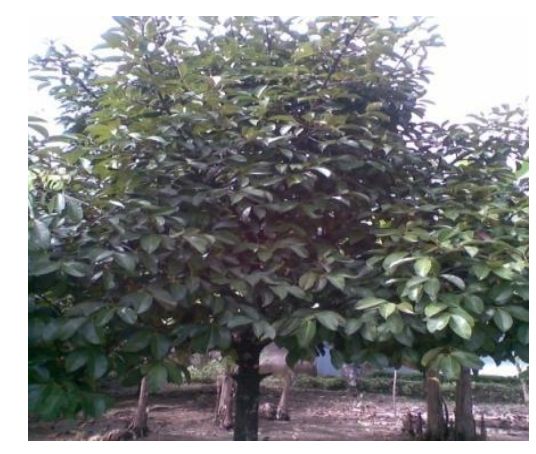

\section{Gambar 1. Tanaman manggis ( $G$ mangostana)}

Daun dan kulit batang manggis segar yang didapatkan, dicuci dengan air yang mengalir untuk membersihkan kotoran atau kontaminan yang berupa tanah, atau materi lain pada daun tersebut. Dipilih daun $(3 \mathrm{~kg})$ dan kulit batang $(1 \mathrm{~kg})$ yang bagus untuk selanjutnya diangin-anginkan dan dikeringkan di bawah sinar matahari yang ditutupi kain hitam. Selama pemanasan, bahan ditata tidak bertumpuk dan dibolak-balik agar pemanasan merata serta proses pengeringan berlangsung cepat. 
Daun manggis sudah kering di hari ke tujuh sedangkan kulit batang manggis kering di hari ke enam. Kulit batang manggis lebih cepat kering, karena kadar air pada kulit batang lebih sedikit dari daun (Anonim, 1985).

Pengeringan dilakukan hingga kadar air kurang dari 10\% atau sampai daun dan kulit batang mudah untuk dihancurkan ketika diremas. Tujuan dari pengeringan adalah mencegah pertumbuhan jamur atau mikroorganisme dan penguraian senyawa aktif oleh reaksi enzimatik dan proses hidrolisis karena kandungan air yang tinggi, agar simplisia yang dihasilkan tidak mudah rusak sehingga dapat disimpan dalam waktu yang relatif lama. Simplisia kering yang diperoleh selanjutnya diserbuk dengan menggunakan blender untuk memperkecil luas permukaan sehingga kontak permukaan partikel simplisia dengan penyari semakin besar dan penyarian lebih optimal.

Simplisia selanjutnya diayak menggunakan ayakan mesh 20/40 yang berarti sebanyak $100 \%$ simplisia kering lolos pada ayakan mesh 20, kemudian sebanyak 40\% dari 100\% simplisia kering lolos ayakan mesh 40, sehingga dari 500 gram simplisia kering daun dan kulit batang manggis sebanyak 300 gram lolos ayakan mesh 20 dan sebanyak 40 gram lolos ayakan 200. Pada umumnya proses penyaringan ini penting dalam proses ekstraksi, karena dengan adanya pengecilan ukuran partikel akan memperluas permukaan kontak serbuk dengan penyari sehingga ekstraksi menjadi lebih maksimal dan kandungan zat aktif dapat tersari secara optimal.

Metode penyarian yang digunakan adalah maserasi. Metode ini merupakan metode yang paling sederhana karena mudah dilakukan, murah, tidak memerlukan peralatan yang canggih. Maserasi dilakukan dengan cara merendam serbuk simplisia dalam cairan penyari. Pada penelitian ini untuk meningkatkan efektifitas ekstraksi dilakukan pengadukan dan remaserasi, dimaserasi selama 2 x 24 jam dengan perbandingan antara simplisia dengan etanol 70\% adalah 1:10 untuk hari pertama, dan 1:4 untuk hari kedua. Caranya yaitu serbuk simplisia sebanyak 500 gram dimaserasi dengan etanol $70 \%$ sebanyak 5 Liter, kemudian dienap-tuangkan dan diperas. Ampas yang diperoleh dimaserasi lagi dengan etanol $96 \%$ sebanyak 2 Liter.

Pada penelitian ini penyari yang digunakan yaitu etanol $70 \%$. Penyari etanol $70 \%$ dapat menarik senyawa - senyawa relatif polar seperti senyawa fenol, flavonoid, saponin, dan senyawa polar lain yang terkandung dalam daun dan kulit batang manggis. Dipilih etanol $70 \%$ karena lebih selektif, tidak beracun, netral, absorbsi baik, dapat mencegah pertumbuhan kapang dan kuman, panas yang diperlukan untuk pemekatan lebih sedikit. Sari yang diperoleh diuapkan di atas penangas air hingga konsistensi kental. Penguapan dilakukan untuk menghilangkan larutan penyari agar tidak mempengaruhi uji aktivitas antioksidan setelah didapatkan ekstrak kental (Gambar 2) seperti yang tertera pada Tabel I berikut ini.

Tabel I. Rendemen ekstrak etanol daun dan kulit batang manggis

\begin{tabular}{cccc}
\hline Jenis & Bobot simplisia awal & Berat ekstrak & Rendemen \\
\hline Daun manggis & $500 \mathrm{~g}$ & $149,28 \mathrm{~g}$ & $29,86 \%$ \\
Kulit batang manggis & $500 \mathrm{~g}$ & $38,99 \mathrm{~g}$ & $7,80 \%$ \\
\hline
\end{tabular}

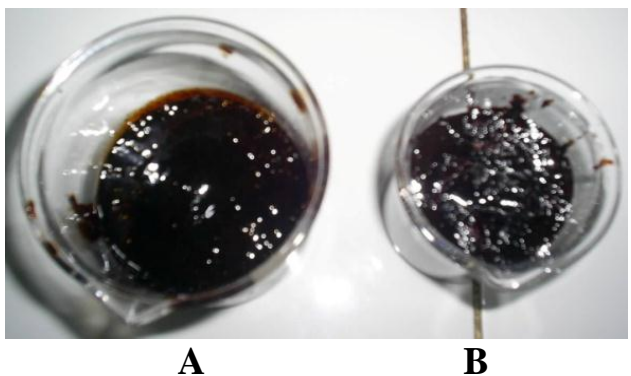

Gambar 2. Ekstrak etanol kental daun (a) dan kulit batang (b) manggis

Daun dan kulit batang G. mangostana L. memiliki kandungan kimia yang banyak tapi hanya senyawa tertentu yang memiliki aktivitas antioksidan. Tumbuhan G. mangostana L. mengandung senyawa metabolit sekunder yang terdapat pada berbagai organ tumbuhan. Kulit buah mengandung 
senyawa xanthone yang meliputi mangostin, mangostenol, mangostinon $\mathrm{A}$, mangostenon $\mathrm{B}$, trapezifolixanthone, tovophyllin B, alfa mangostin, beta mangostin, garcinon B, mangostanol, flavonoid epicatechin, dan gartanin. Kandungan kimia kulit buah manggis adalah Xanton ( mangostin, garsinon) flavonoid dan tanin (Heyne, 1997; Soedibyo, 1998). Xanton merupakan derivate dari difenil$\gamma$-piron, xanton terdistribusi luas pada tumbuhan tinggi, tumbuhan paku, lumut dan jamur. Sebagian besar xanton ditemukan pada empat suku tumbuhan tinggi yaitu, Guttiferae, moraceae, poligalaceae, gentianaceae (Sluis, 1985).

Pengujian antioksidan dilakukan terhadap ekstrak etanol daun dan kulit batang G. mangostana L. serta $\alpha$-d-tokoferol (vitamin E) sebagai pembanding. Potensi antioksidan penangkap radikal ditentukan dengan menggunakan DPPH, suatu radikal sintetik yang stabil dalam larutan air atau metanol dan mampu menerima sebuah elektron atau radikal hidrogen untuk menjadi molekul diamagnetik yang stabil. DPPH pada uji ini ditangkap oleh antioksidan yang melepaskan hidrogen, sehingga membentuk DPPH tereduksi (DPP-Hidrazin). Perubahan warna violet DPPH menjadi kuning diikuti penurunan serapan pada panjang gelombang maksimum $(516 \mathrm{~nm})$, ini menunjukkan adanya aktivitas antioksidan yang dapat dilihat dari \% peredaman (Sunarni, 2007).

Mekanisme kerja antioksidan adalah meredam radikal bebas dengan memberikan satu atau lebih elektronnya pada radikal bebas sehingga menjadi bentuk molekul yang normal kembali. Kemampuan flavonoid sebagai antioksidan disebabkan oleh adanya gugus katekol pada cincin B yang berperan sebagai donor elektron. Pola oksigenasi pada cincin B yang ditunjukkan oleh gugus orto hidroksi pada posisi 3 dan 4 berperan sebagai antioksidan. Reaksi antara senyawa flavonoid orto hidroksi (misal: rutin) dengan radikal bebas DPPH dapat dilihat pada Gambar 3. Reaksi ini menghasilkan senyawa radikal baru yang stabil (flavonoid kuinon) dan DPP-Hidrazin yang distabilkan resonansi (Windono dkk., 2004).

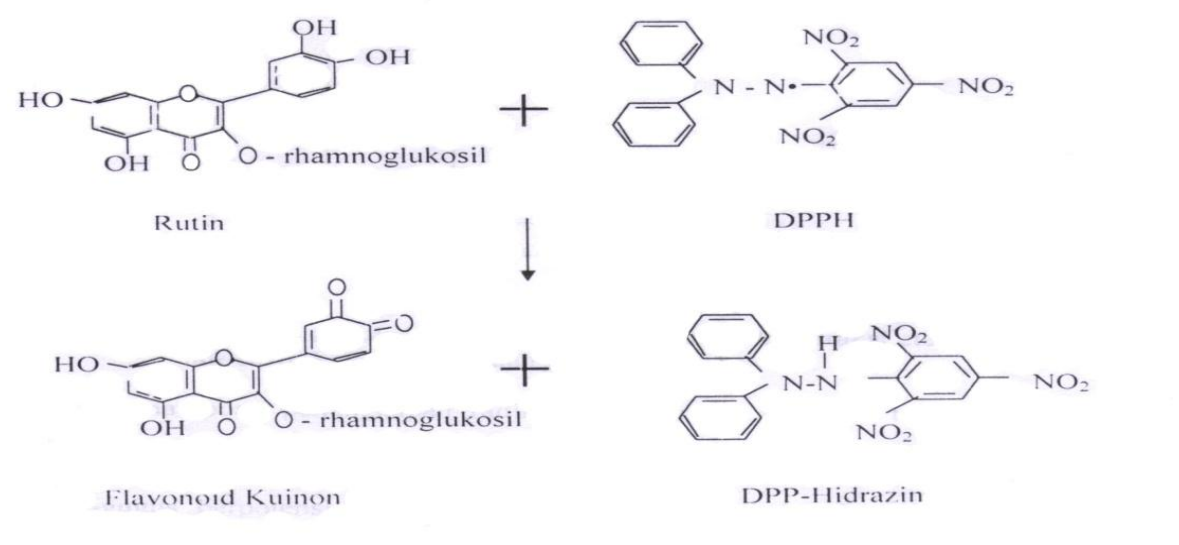
Gambar 3. Reaksi kimia rutin dengan DPPH sebagai radikal bebas (Windono dkk.,
2004).

Daun dan kulit batang G. mangostana L.mengandung polifenol yang berperan besar dalam pencegahan berbagai penyakit. Polifenol ini seratus kali lebih efektif dari vitamin C dan 25 kali lebih efektif dari vitamin E. Zat ini juga berfungsi untuk menetralisir radikal bebas. Daun dan kulit batang G. mangostana L. mengandung Xanton (mangostin, garsinon) flavonoid dan tanin yang berfungsi sebagai prekursor menangkap (scavenger) senyawa radikal oksigen (ROS). Flavonoid memiliki aktivitas antioksidan yang berfungsi sebagai pengikat unsur logam berbahaya dalam tubuh. Pada tanaman beberapa senyawa fenolik merupakan antioksidan potensial: flavonoid, tanin, dan lignin merupakan prekursor yang bekerja pada penangkapan senyawa ROS.

Pada saat ini penggunaan antioksidan sintetik seperti Torlok $\mathrm{C}$, Prowl galat, dan monotertiery-butyl-hidroquinone (TBHQ) sedang mendapat perhatian karena mempunyai efek mengurangi kerusakan oksidatif, namun mempunyai aktivitas yang dapat merugikan konsumen, antara lain gangguan fungsi hati, paru paru, mukosa usus, dan keracunan. Untuk mengatasi hal tersebut sebaiknya dipilih antoksidan dari bahan alami. 
Pengukuran dilakukan dengan mengambil salah satu larutan konsentrasi, diambil $100 \mathrm{~mL}$ metanol dan di tambah 0,004 g DPPH, dibaca absorbansi nya pada panjang gelombang $516 \mathrm{~nm}$ dari menit ke : $0,5,10,15,20,25,30,35,40,45,50,55,60$. Hasil penentuan operating time ditetapkan waktu 30 menit, hal ini berdasarkan metode yang ada menurut Gulluce (2006), dengan melihat profil operating time (Gambar 4), maka penentuan absorbansi pada menit ke 30 harus tepat waktu, karena dengan bertambahnya waktu akan terjadi perubahan absorbansi yang berarti.

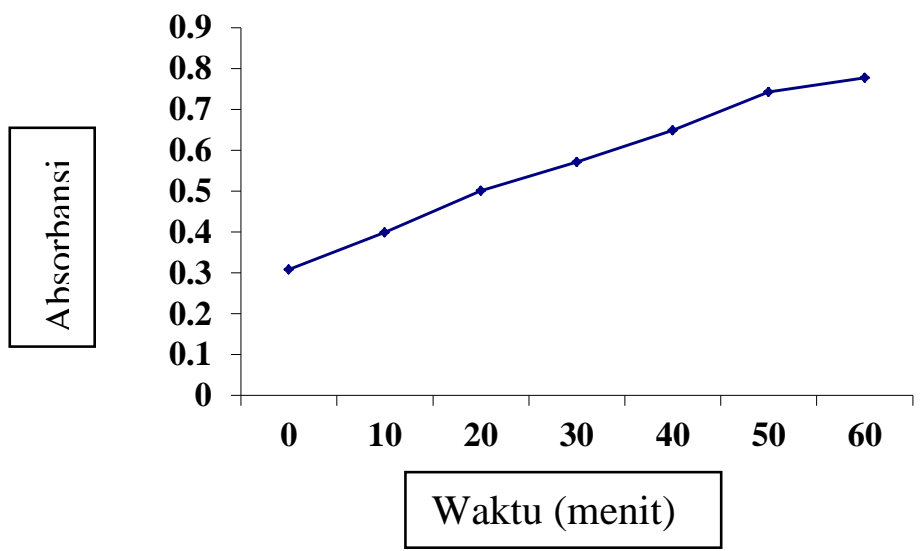

Gambar 4. Grafik penentuan operating time larutan DPPH

Pengukuran absorbansi yang diperoleh dari pemipetan larutan DPPH sebanyak 0,004 g dan metanol sebanyak $100 \mathrm{~mL}$ pada panjang gelombang $516 \mathrm{~nm}$ memperlihatkan bahwa absorbansi larutan DPPH tertinggi untuk uji aktivitas antioksidan ekstrak etanol adalah 0,337. Absorbansi tertinggi larutan DPPH baik untuk uji aktivitas antioksidan ekstrak etanol daun dan kulit batang G. mangostana L. maupun BHT dan d-alfa tokoferol diperoleh panjang gelombang $516 \mathrm{~nm}$. Ini berarti pengukuran absorbansi pada uji aktivitas antioksidan ekstrak etanol daun dan kulit batang G. mangostana L. dan rutin dilakukan pada $\lambda$ maks $516 \mathrm{~nm}$.

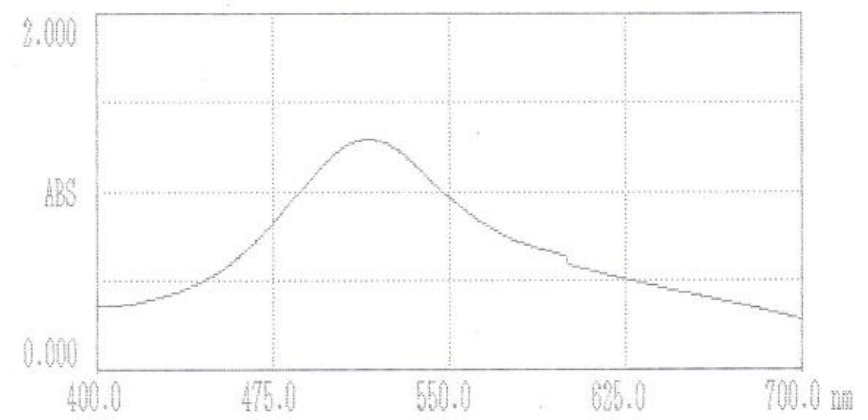

Gambar 5. Hasil penentuan panjang gelombang maksimum larutan DPPH

Hasil uji aktivitas antioksidan penangkap radikal bebas DPPH dapat dilihat dari persentase peredaman ekstrak etanol daun dan kulit batang G. mangostana L. serta $\alpha$-d-tokoferol (vitamin E) sebagai pembanding berturut-turut ditunjukkan pada Tabel II.

Hasil (Tabel II) menunjukkan bahwa ekstrak etanol daun dan kulit batang G. mangostana L. mempunyai daya antioksidan dengan metode $\mathrm{DPPH}$ dengan nilai $\mathrm{IC}_{50}$ sebesar $674,947 \mathrm{ug} / \mathrm{mL}$ dan $565,759 \mathrm{ug} / \mathrm{mL}$. $\mathrm{IC}_{50}$ merupakan konsentrasi ekstrak etanol daun dan kulit batang manggis yang mampu memberikan persen penangkapan radikal sebanyak $50 \%$ dibanding kontrol melalui suatu persamaan garis regresi linier, semakin kecil nilai $\mathrm{IC}_{50}$ berarti semakin kuat daya antioksidannya. Nilai $\mathrm{IC}_{50}$ ini jauh lebih besar daripada nilai $\mathrm{IC}_{50}$ vitamin $\mathrm{E}$ yakni sebesar $57,114 \mathrm{ug} / \mathrm{mL}$. Hal ini menunjukkan bahwa daya antioksidan ekstrak etanol daun dan kulit batang G. mangostana L. 11 dan 10 kali lebih kecil dibanding daya antioksidan vitamina E dengan menggunakan metode DPPH. 
Tabel II. Aktivitas antioksidan ekstrak etanol daun dan kulit batang G. mangostana

\begin{tabular}{|c|c|c|c|c|}
\hline $\begin{array}{l}\text { Kadar } \\
\text { ug/mL }\end{array}$ & Absorbansi & $\begin{array}{r}\text { Aktivitas } \\
\text { Antioksidan }\end{array}$ & $\mathrm{IC}_{50}(\mathrm{u}$ & $\mathrm{g} / \mathrm{mL})$ \\
\hline Ekstrak & Daun & & & \\
\hline$\overline{\text { Replikas }}$ & & & & \\
\hline 100 & 0,774 & 13,712 & $Y=0,071 X+7,639$ & \\
\hline 200 & 0,678 & 24,415 & $\mathrm{IC}_{50}=596,634$ & \\
\hline 400 & 0,589 & 34,337 & & \\
\hline 800 & 0,312 & 65,217 & & \\
\hline Replikas & & & & \\
\hline 100 & 0,862 & 3,902 & $Y=0,069 X+6,548$ & $\mathrm{IC}_{50}$ rata-rata $=$ \\
\hline 200 & 0,837 & 6,689 & $\mathrm{IC}_{50}=819,536$ & $674,947 \mathrm{ug} / \mathrm{mL}$ \\
\hline 400 & 0,756 & 15,719 & & \\
\hline 800 & 0,439 & 51,059 & & \\
\hline Replikas & & & & \\
\hline 100 & 0,788 & 12,152 & $Y=0,079 X+1,915$ & \\
\hline 200 & 0,738 & 17,762 & $\mathrm{IC}_{50}=608,947$ & \\
\hline 400 & 0,626 & 30,212 & & \\
\hline 800 & 0,292 & 67,447 & & \\
\hline Ekstrak & Kulit Batang & & & \\
\hline Replikas & & & & \\
\hline 100 & 0,769 & 14,269 & $Y=0,075 X+8,104$ & \\
\hline 200 & 0,705 & 21,405 & $\mathrm{IC}_{50}=558,613$ & \\
\hline 400 & 0,509 & 43,255 & & \\
\hline 800 & 0,301 & 66,444 & & \\
\hline Replikas & & & & \\
\hline 100 & 0,752 & 16,165 & $Y=0,070 X+10,242$ & $\mathrm{IC}_{50}$ rata-rata \\
\hline 200 & 0,689 & 23,188 & $\mathrm{IC}_{50}=567,971$ & $565,759 \mathrm{ug} / \mathrm{ml}$ \\
\hline 400 & 0,526 & 41,360 & & \\
\hline 800 & 0,317 & 64,659 & & \\
\hline Replikas & & & & \\
\hline 100 & 0,778 & 13,266 & $Y=0,078 X+5,486$ & \\
\hline 200 & 0,716 & 20,178 & $\mathrm{IC}_{50}=570,692$ & \\
\hline 400 & 0,555 & 38,127 & & \\
\hline 800 & 0,292 & 67,447 & & \\
\hline Vitamin & & & & \\
\hline Replikas & & & & \\
\hline 20 & 0,802 & 10,591 & $Y=0,937 X-4,493$ & \\
\hline 40 & 0,509 & 34,225 & $\mathrm{IC}_{50}=58,157$ & \\
\hline 60 & 0,419 & 53,289 & & \\
\hline 80 & 0,195 & 78,261 & & \\
\hline 100 & 0,159 & 82,274 & & \\
\hline Replikas & & & & \\
\hline 20 & 0,729 & 18,729 & $Y=0,853 X+3,556$ & $\mathrm{IC}_{50}$ rata-rata $=$ \\
\hline 40 & 0,552 & 38,462 & $\mathrm{IC}_{50}=54,448$ & 57,114 ug/ml \\
\hline 60 & 0,376 & 57,748 & & \\
\hline 80 & 0,259 & 71,126 & & \\
\hline 100 & 0,110 & 87,737 & & \\
\hline Replikas & & & & \\
\hline 20 & 0,799 & 10,925 & $Y=0,987 X+7,972$ & \\
\hline 40 & 0,614 & 31,549 & $\mathrm{IC}_{50}=58,736$ & \\
\hline 60 & 0,427 & 52,397 & & \\
\hline 80 & 0,251 & 72,018 & & \\
\hline 100 & 0,095 & 89,409 & & \\
\hline
\end{tabular}

Absorbansi kontrol 0,897 


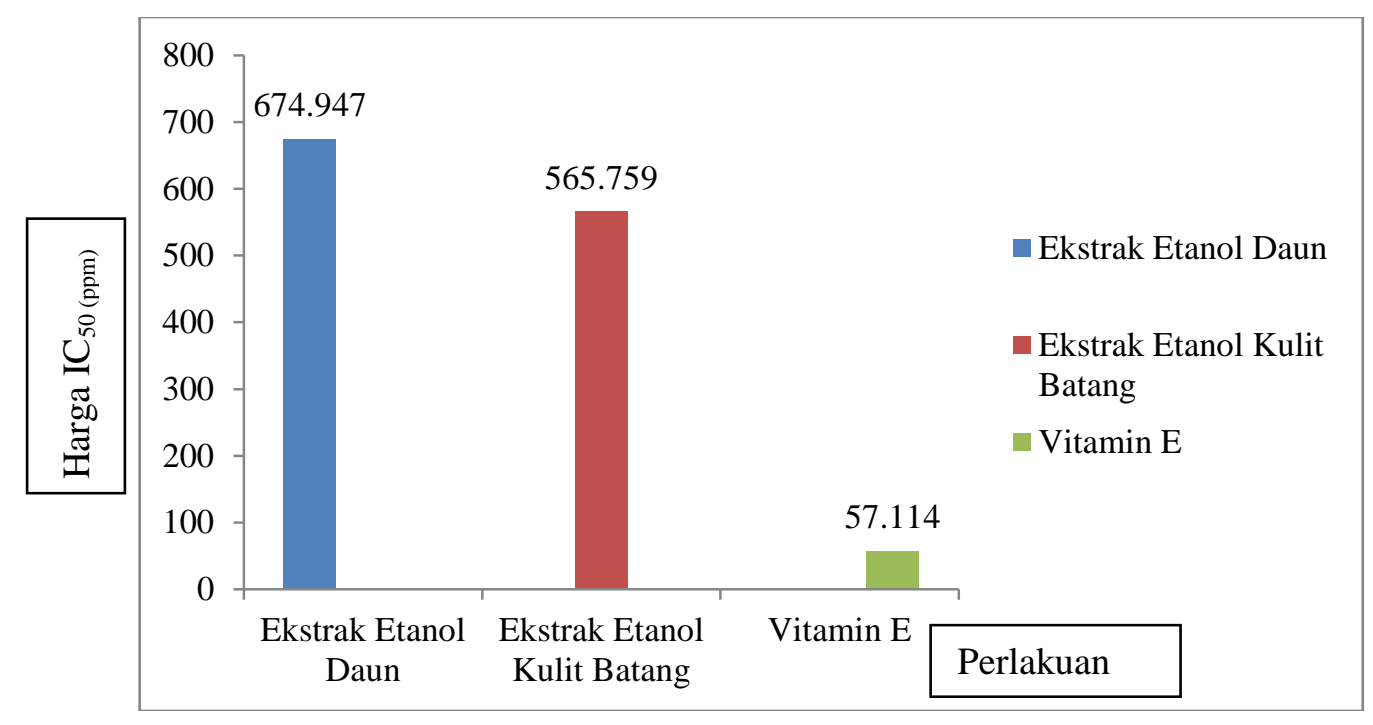

\section{Gambar 6. Aktivitas antioksidan penangkap radikal DPPH ekstrak etanol daun dan kulit batang G. mangostana L., pembanding Vitamin E}

Berdasarkan hasil perhitungan antara konsentrasi larutan uji terhadap \% peredaman pada Tabel II, didapatkan data yang menyatakan bahwa ada korelasi positif antara konsentrasi semua larutan uji dengan \% peredaman, artinya semakin tinggi konsentrasi larutan uji, maka semakin tinggi daya peredamannya. Dilihat dari $\mathrm{IC}_{50}$ nya, ekstrak etanol daun dan kulit batang memiliki $\mathrm{IC}_{50}$ sebesar $674,947 \mathrm{ug} / \mathrm{mL}$ dan $565,759 \mathrm{ug} / \mathrm{mL}$ menunjukkan bahwa pada konsentrasi tersebut sudah mampu meredam $50 \%$ aktivitas radikal DPPH pada periode waktu 30 menit. Berdasarkan hasil tersebut dapat dikatakan bahwa ekstrak etanol daun dan kulit batang G. mangostana L. mempunyai aktivitas dalam menghambat radikal bebas DPPH. Vitamin E sebagai pembanding memiliki $\mathrm{IC}_{50}$ sebesar 57,114 ug/mL. Aktivitas antioksidan penangkap radikal bebas DPPH ekstrak etanol daun dan kulit batang manggis serta pembanding dapat dilihat pada Gambar 5.

Kemampuan penangkapan radikal bebas ekstrak etanol daun dan kulit batang G. mangostana L., kemungkinan dikarenakan ekstrak etanol daun dan kulit batang G. mangostana L. mengandung senyawa polifenol dan flavonoid dengan gugus-gugus berpotensi kuat sebagai penangkap radikal bebas, sehingga dapat meningkatkan aktivitas antioksidannya, gugus orto dihidroksi pada flavonoid yang dimungkinkan paling berpengaruh kuat sebagai antioksidan penangkap radikal bebas. Reaksi yang terjadi, analog dengan reaksi rutin dengan DPPH pada Gambar 3.

Hasil penelitian dengan anava satu jalan dengan taraf kepercayaan 95\% menunjukkan bahwa ekstrak daun dan kulit batang G. mangostana L. memiliki aktivitas antioksidan yang sama terhadap radikal bebas DPPH (1,1-difenil-2-pikril hidrazil), namun berbeda jika dibandingkan antioksidan vitamin E. Dengan mempertimbangkan hal tersebut maka, ekstrak etanol daun dan kulit batang $G$. mangostana L. potensial untuk dikembangkan sebagai antioksidan alami.

\section{KESIMPULAN}

Ekstrak etanol daun dan kulit batang G. mangostana L. mempunyai aktivitas antioksidan yaitu memiliki $\mathrm{IC}_{50}$ sebesar $674,947 \mathrm{ug} / \mathrm{mL}$ dan $565,759 \mathrm{ug} / \mathrm{mL}$ yang sama terhadap radikal bebas DPPH. Hasil analisis varian satu arah pada taraf kepercayaan 95\%, ekstrak etanol daun dan kulit batang $G$. mangostana L. mempunyai aktivitas antioksidan yang sama, namun berbeda terhadap pembanding Vitamin $\mathrm{E}\left(\mathrm{IC}_{50} 57,114 \mathrm{ug} / \mathrm{mL}\right)$ yaitu lebih kecil 11 dan $10 \mathrm{kali}$.

\section{DAFTAR PUSTAKA}

Anonim, 2009, Manggis, Deputi Menegristek Bidang Pendayagunaan dan Permasyarakatan Ilmu Pengetahuan dan Teknologi. http://www.ristek.go.id.[15 September 2009]

Gulluce, M., Aslan A., Sokmen, M., Sahin, F., Adiguzel, A., Agar, A., Sokmen, A., 2006, Screening the antioxidant and antimicrobial properties of the lichens Parmelia saxatilis, Platismatis 
glauca, Ramalina pollinaria, Ramalina polymorpha and Umbilicaria nylanderiana, J.Phytomedicine 13(2006), p.515-521

Heyne, K., 1987, Tumbuhan Berguna Indonesia III, Penerjemah: Badan Penelitian dan pengembangan Kehutanan, Yayasan Sarana Wahajaya, Jakarta.

Jung H, Su B, Keller W, Mehta R, kinghorn A. 2006. Antioxidant xanthones from the pericarp of Garcinia mangostana (mangosteen). J.agric.food Chem. 54(6) pp 2077-2082

Qosim, W.A., 2007, Kulit Buah Manggis sebagai Antioksidan. Available at http://pikiranrakyat.com./cetak/2007/022007/15/kampus/lain01.htm

Mardawati,E., Filianty, F., Marta, H., 2010, Kajian Aktivitas Antioksidan Ekstrak Kulit manggis (Garcinia mangostana L., ) dalam rangka Pemanfaatan Limbah Kulit Manggis di Kecamtatan Puspahlang Kabupaten Tasikmalaya, Lembaga Penelitian UNPAD

Marisi RT, Soediro S, Elin YS., 1998, Telaah Kandungan Kimia dan Aktivitas Antimikroba Kulit Buah Manggis ( Garcinia Mangostana, L. Guttiferae), http:// bahan-alam.fa.itb.ac.id. [17 September 2009].

Morton, J. 1987. Mangosteen. In: Fruits of warm climates. Julia F. Morton. Miami, FL. P. 301-304.

Muharni, Supriyatna, Husein H. bahti, Dacharianus. 2009. Aktivitas Antioksidan Senyawa Fenol dari Manggis Hutan (Garcinia bancana Miq.), Jurnal Penelitian Sains, Volume 12 (3), 12307.

Peraturan Menteri Kesehatan Nomor : 722/Menkes/Per/IX/88 Tentang Bahan Tambahan Makanan

Schulz, V., Hänsel R, Tyler V E. 1998, Rational Phytotherapy: A Physicians' Guide to Herbal Medicine, Springer, Germany

Sluis, W.G., 1985, Secoiridoids And Xanthones In Genus Centaurium Hill (Gentianaceae), Drukkerij Elinkwijk bv, Utrecht.

Soedibyo, M., 1998, Alam Sumber Kesehatan, Balai Pustaka, Jakarta

Steenis VCGGC, Blombergen S, PJ Eyma, 1947, Flora, penerjemah Moeso Surjowinoto, PT. Pradnya Paramita, Jakarta.

Sunarni, 2007, Flavonoid Antioksidan Penangkap Radikal Dari Daun Kepel (Stelechocarpus burahol (Bl.) Hookf. \& Th.), Majalah Farmasi Indonesia, 18(3), $111-116$

Tambunan, R. M., 1998, Telaah Kandungan dan aktivitas antimikroba kulit buah manggis (Garcinia mangostana L.), Jurusan Farmasi, Fakultas MIPA ITB, Bandung

Widowati E, 2006, Pengaruh Lama Perendaman dengan Buah Manggis Terhadap Kualitas Bahan Kembang Gula Jelly, Skripsi, UNS, Semarang.

Winarsi, H, 2007. Antioksidan Alami dan Radikal Bebas. Yogyakarta : Kanisius

Windono,T., Budiono, R., Ivone, Valentina, S. dan Saputro, Y., 2004, Studi Hubungan StrukturAktivitas Kapasitas Peredaman Radikal Bebas Senyawa Flavonoid terhadap 1,1-Difenil-2Pikrilhidrazil ( DPPH ), Artocarpus, Surabaya, 4 (1) : 47-51. 
